\title{
Global impact of road traffic emissions on tropospheric ozone
}

\author{
S. Matthes ${ }^{1}$, V. Grewe ${ }^{1}$, R. Sausen ${ }^{1}$, and G.-J. Roelofs ${ }^{2}$ \\ ${ }^{1}$ Institut für Physik der Atmosphäre, DLR-Oberpfaffenhofen, Wessling, Germany \\ ${ }^{2}$ Institut for Marine Research, University of Utrecht, Utrecht, The Netherlands
}

Received: 15 August 2005 - Published in Atmos. Chem. Phys. Discuss.: 24 October 2005

Revised: 15 December 2006 - Accepted: 15 January 2007 - Published: 29 March 2007

\begin{abstract}
Road traffic is one of the major anthropogenic emission sectors for $\mathrm{NO}_{\mathrm{x}}, \mathrm{CO}$ and NMHCs (non-methane hydrocarbons). We applied ECHAM4/CBM, a general circulation model coupled to a chemistry module, which includes higher hydrocarbons, to investigate the global impact of 1990 road traffic emissions on the atmosphere. Improving over previous global modelling studies, which concentrated on road traffic $\mathrm{NO}_{\mathrm{x}}$ and $\mathrm{CO}$ emissions only, we assess the impact of NMHC emissions from road traffic. It is revealed that NMHC emissions from road traffic play a key role for the impact on ozone. They are responsible for (indirect) longrange transport of $\mathrm{NO}_{\mathrm{x}}$ from road traffic via the formation of PAN, which is not found in a simulation without NMHC emissions from road traffic. Long-range transport of NMHCinduced PAN impacts on the ozone distribution in Northern Hemisphere regions far away from the sources, especially in arctic and remote maritime regions. In July total road traffic emissions $\left(\mathrm{NO}_{\mathrm{x}}, \mathrm{CO}\right.$ and $\left.\mathrm{NMHCs}\right)$ contribute to the zonally averaged ozone distribution by more than $12 \%$ near the surface in the Northern Hemisphere midlatitudes and arctic latitudes. In January road traffic emissions contribute near the surface in northern and southern extratropics more than $8 \%$. Sensitivity studies for regional emission show that effective transport of road traffic emissions occurs mainly in the free troposphere. In tropical latitudes of America up to an altitude of $200 \mathrm{hPa}$, global road traffic emissions contribute about $8 \%$ to the ozone concentration. In arctic latitudes NMHC emissions from road transport are responsible for about $90 \%$ of PAN increase from road transport, leading to a contribution to ozone concentrations of up to $15 \%$.
\end{abstract}

Correspondence to: S. Matthes

(sigrun.matthes@dlr.de)

\section{Introduction}

Ozone plays an important role in the troposphere due to its impact on the oxidizing capacity of the atmosphere, on air quality, and its contribution to the greenhouse effect. In the atmosphere $\mathrm{NO}_{\mathrm{x}}, \mathrm{CO}$ and NMHCs act as ozone precursors, by forming radicals which finally contribute to ozone formation (Crutzen et al., 1999). CO and NMHCs are oxidized by $\mathrm{OH}$ while nitric oxide determines oxidation pathways possibly leading to ozone production. The relevant $\mathrm{NO}_{2}$ related reactions are:

$$
\begin{aligned}
& \mathrm{NO}+\mathrm{O}_{3} \rightarrow \mathrm{NO}_{2}+\mathrm{O}_{2} \\
& \mathrm{NO}_{2}+\mathrm{O}_{2} \rightarrow \mathrm{O}_{3}+\mathrm{NO} \\
& \mathrm{NO}+\mathrm{HO}_{2} \rightarrow \mathrm{NO}_{2}+\mathrm{OH} \\
& \mathrm{O}_{3}+\mathrm{HO}_{2} \rightarrow 2 \mathrm{O}_{2}+\mathrm{OH}
\end{aligned}
$$

Reaction (R2) is a net reaction of the photolysis of $\mathrm{NO}_{2}$ and subsequent ozone formation. Reactions (R1) and (R2) describe a photostationary equilibrium of $\mathrm{NO} / \mathrm{NO}_{2}$ and $\mathrm{O}_{3}$ without net ozone production. Only if ozone is substituted in $\mathrm{NO}_{2}$-formation (Reaction R3) a net ozone production takes place. These conditions apply above a threshold in the NO mass mixing ratio (typically above $10-30 \mathrm{ppt}$ ) when $\mathrm{HO}_{2}$ reacts preferably with $\mathrm{NO}$ (R3) and not with $\mathrm{O}_{3}$ (Reaction R4). As $\mathrm{HO}_{2}$ is formed during oxidation of $\mathrm{CO}$ and NMHCs (Crutzen et al., 1999; Atkinson, 1990), their emissions are influencing significantly the above described photochemistry.

Road traffic is one of the main emitters of these ozone precursors, formed by the combustion of fossil fuels inside internal combustion engines (gasoline and diesel). Although since the nineties reductions in road traffic specific emissions were achieved in certain regions due to the introduction of catalytic converters resulting in decreasing emission indices, global emissions are still supposed to grow in the future (OECD, 1995),(IPCC, 2000). Reasons for this are both,

Published by Copernicus GmbH on behalf of the European Geosciences Union. 
Table 1. Global annual anthropogenic emissions of nitrogen oxides $\left(\mathrm{NO}_{\mathrm{x}}\right)$, carbon monoxide $(\mathrm{CO})$ and non-methane hydrocarbons (NMHCs), for references see text. Anthropogenic total, fossil fuel combustion and herein included emissions due to road traffic are given $(\mathrm{o} / \mathrm{w}=$ of which $)$.

\begin{tabular}{lrrr}
\hline Emissions & $\begin{array}{r}\mathrm{NO}_{\mathrm{x}} \\
\mathrm{Tg}[\mathrm{N}]\end{array}$ & $\begin{array}{r}\mathrm{CO} \\
\mathrm{Tg}[\mathrm{CO}]\end{array}$ & $\begin{array}{c}\mathrm{NMHCs} \\
\mathrm{Tg}[\mathrm{C}]\end{array}$ \\
\hline Anthropogenic & 27.6 & 678.4 & 108.2 \\
Fossil fuel & 22.6 & 478.4 & 35.4 \\
o/w road traffic & 8.8 & 236.9 & 26.6 \\
\hline
\end{tabular}

traffic growth rates, e.g. in developing regions, and fuel intense vehicles counteracting mitigation strategies. In contrast to other transport modes, e.g. shipping and aviation, only few global modelling studies on the impact of road traffic exist. E.g., Granier and Brasseur (2003) investigated the impact of $\mathrm{NO}_{\mathrm{x}}$ and $\mathrm{CO}$ emissions from road traffic and estimated relative contribution of such emissions to ozone concentrations near the surface in the Northern Hemisphere of between $12 \%$ and $15 \%$ in industrialized regions and about $9 \%$ in remote regions. In our study we also consider the additional impact of NMHC emissions from road traffic. The related impact on climate is dealt within a forthcoming paper (Matthes et al., $2007^{1}$ ).

The applied global atmosphere-chemistry model, emission data and experimental setup are described in Sect. 2. In Sect. 3 simulated $\mathrm{NO}_{2}$ columns are evaluated against satellite data, and extending results of existing model evaluation (Roelofs and Lelieveld, 2000; Houweling et al., 1998). In Sect. 4, results of our modelling study are presented and discussed, with respect to the effect of total road traffic emissions, individual contributions from $\mathrm{NO}_{\mathrm{x}}, \mathrm{CO}$, and NMHCs emissions, and with respect to regional road traffic emissions. Section 5 gives a summary and concludes this study.

\section{Model, emissions, and experimental setup}

In order to study the impact of road traffic emissions on the atmospheric composition we use the global circulation model ECHAM4 (Roeckner et al., 1996) coupled to the chemistry module CBM-IV (Gery et al., 1989), using a parameterized stratospheric chemistry. The coupled model system (ECHAM4/CBM) has been developed and adapted for global modelling (Roelofs and Lelieveld, 2000). ECHAM4 is a spectral general circulation model which solves the primitive equations; for the present study it is used in T30 horizontal resolution with 19 layers vertical resolution (model top layer centered at $10 \mathrm{hPa}$ ), model physics is calculated

\footnotetext{
${ }^{1}$ Matthes, S., Stuber, N., Grewe, V., and Ponater, M.: Radiative forcing of road transport emissions, in preparation, 2007.
}

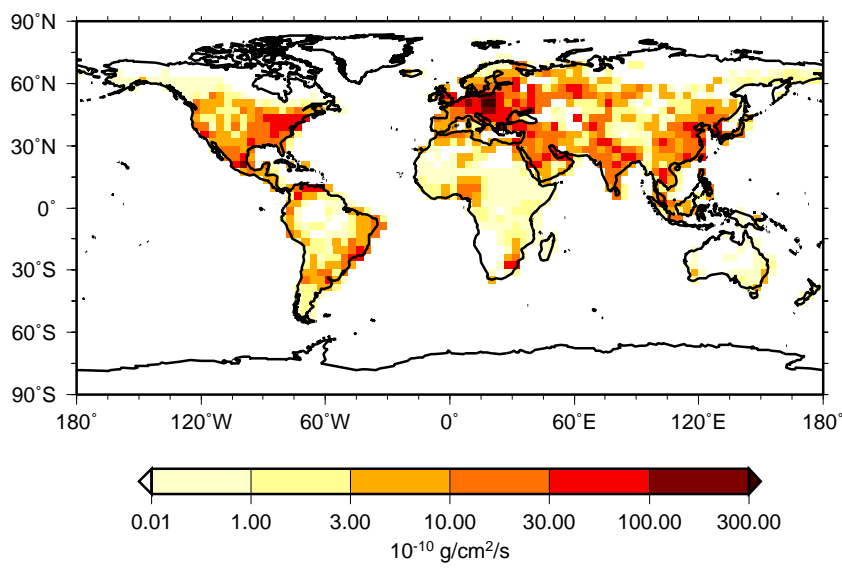

Fig. 1. $\mathrm{NO}_{\mathrm{x}}$ emission $\left[10^{-11} \mathrm{~g} \mathrm{~cm}^{-2} \mathrm{~s}^{-1}\right]$ from road traffic in 1990.

on the associated Gaussian grid of about $3.75^{\circ} \times 3.75^{\circ}$ geographical longitude vs. latitude. Water vapour, cloud water and the 35 tracers included in the chemistry model are transported by a semi-Lagrangian advection scheme. CBM-IV is a carbon-bond-mechanism based on structural lumping with explicit representation of e.g. alkanes, alkenes, isoprene, aceton, formaldehyde. Aromatic compounds are neglected in the scheme used here, but sensitivity experiments performed with our chemistry model give a lower estimate of the contribution of aromatic compounds to atmospheric ozone in the order of 3\% in strongly confined regions.

Emissions are implemented as flux boundary conditions into the model system. The year 1990 was chosen as reference year, since complete emission data and atmospheric observations were available. Global values of anthropogenic emissions $\left(\mathrm{NO}_{\mathrm{x}}, \mathrm{CO}\right.$, and $\left.\mathrm{NMHCs}\right)$ are given in Table 1. Anthropogenic $\mathrm{NO}_{\mathrm{x}}$ emissions amount to $27.6 \mathrm{Tg}$ and include 5.0 Tg from biomass burning (Hao and Liu, 1994) and 22.6 Tg from fossil fuel combustion (Benkovitz et al., 1996). Natural $\mathrm{NO}_{\mathrm{x}}$ emissions from soils and lightning account for $5.5 \mathrm{Tg}$ and $5.0 \mathrm{Tg}$, respectively. NMHC emissions from industry/traffic, biomass burning and vegetation (isoprene) add up to $90 \mathrm{Tg}[\mathrm{C}], 18 \mathrm{Tg}[\mathrm{C}]$ and $400 \mathrm{Tg}[\mathrm{C}]$, respectively. Road traffic emissions (Matthes, 2003; Matthes and Sausen, 2000) of nitrogen oxide (included within fossil fuel combustion) were calculated from the fossil fuel related emissions (Benkovitz et al., 1996) by extracting the fraction of road traffic given by Olivier et al. (1996). The geographical distribution of $\mathrm{NO}_{\mathrm{x}}$ emissions from road traffic is shown in Fig. 1. Carbon monoxide emissions from fossil fuel combustion are taken from Olivier et al. (1996), but have been enhanced by $15 \%$ to yield the global amount given in OECD (1995). Emissions from biomass burning are adopted from Hao and Liu (1994). The NMHC emissions from road traffic were adapted according to Houweling et al. (1998): individual emitted NMHC species (Olivier et al., 1996) are 
lumped and thereby included in the carbon-bond-scheme of the chemistry module according to Gery et al. (1989). With this procedure around $80 \%$ of total mass of NMHC emissions according to Olivier et al. (1996) can be integrated into the model.

To determine the impact of emissions from road traffic, a number of individual simulations were performed (Table 2): a control run (CTR90) and six scenario simulations. A scenario consists of identical conditions except those emissions which are to be investigated are excluded in the model system. Three scenarios for individual species emitted by road traffic (No_NOx, No_NMHC, No_CO), one excluding all road traffic emissions (No_rt), and two scenarios without all road traffic emissions in a specific region (No_rtusa, No_rteur) were calculated. The impact of the individual road traffic emission component is then calculated as the difference between the respective scenario and CTR90 on a monthly mean basis (four years averaging period after two years spin-up time). This approach has been widely used. However it differs from the methodology applied by Granier and Brasseur (2003). They use an averaged meteorology whereas we average the chemical impact and hence allow more non-linearities, e.g. a larger variability in transport affecting chemistry.

\section{Comparison with observations}

The modelling system used in our study was intensively evaluated within earlier papers, the most prominent being Roelofs and Lelieveld (2000). They showed that seasonality of surface $\mathrm{CO}$ and PAN agrees well with observations. Some differences occur associated with representation of biomass burning emissions (CO) and reduced variability in model simulations (PAN). Additonally they compare ozone station data and sonde data with model values for surface, lower, middle and upper troposphere, showing well reproduced seasonal cycle at all altitudes. The representation of the atmospheric $\mathrm{NO}_{\mathrm{x}}$ distribution is of crucial importance for the simulation of the impact of road traffic emission. Satellite data of tropospheric $\mathrm{NO}_{2}$ have been made available only recently (Richter and Burrows, 2002) from the GOME measurements. We compare these with simulated $\mathrm{NO}_{2}$ columns based on monthly means of four consecutive years, following Lauer et al. (2002), who applied the so-called tropospheric excess method (TEM) on model data. We used monthly mean $\mathrm{NO}_{2}$ columns averaged from half hour values, as Lauer et al. (2002) showed that sampling time does not influence the seasonal cycle. However, total amounts may be overestimated by $20 \%$ in Europe and $30-50 \%$ in Africa (Martin et al., 2002). As year of simulation and observation years are different a comparison of main patterns can be performed only.

Figure 2 gives a global picture of the model's capability and indicates that the model system is able to capture the main pattern of the atmospheric $\mathrm{NO}_{\mathrm{x}}$ distribution. Nega-
Table 2. Overview of model simulations performed; rt = road transport, $\mathrm{w} / \mathrm{o}=$ without.

\begin{tabular}{|c|c|}
\hline Name & Description \\
\hline & Base runs \\
\hline CTR90 & emissions from all sources \\
\hline No_rt & w/o $\mathrm{NO}_{\mathrm{x}}, \mathrm{NMHCs}, \mathrm{CO}$ from road traffic \\
\hline & Effect of individual emission \\
\hline No_NOx & w/o $\mathrm{NO}_{\mathrm{x}}$ from road traffic \\
\hline No_NMHC & w/o NMHC from road traffic \\
\hline No_CO & w/o CO from road traffic \\
\hline & Regional effects \\
\hline No_rtusa & w/o emissions from road traffic in USA \\
\hline No_rteur & w/o emissions from road traffic in Europe \\
\hline
\end{tabular}

tive values indicate that the reference sector in this latitude is not free of tropospheric contributions to the total $\mathrm{NO}_{2}$ column (see also discussion on application of TEM below). A conclusion on the quantitative model performance is hard to draw, first, because of uncertainties in the observational data caused by clouds and a low sensitivity in surface-near $\mathrm{NO}_{2}$, which may dominate the total tropospheric column, and, second, because of different meteorology between observational data and modelled data. The tropospheric $\mathrm{NO}_{2}$ columns are influenced by vertical mixing within the boundary layer, which is determined by the respective meteorological conditions. As a general circulation model calculates its own meteorological state and does not use measured meteorological data as input, these conditions can differ quite substantially between different individual periods from modelling studies and observations. As observational data in winter is sparse, this can become prominent then. A vertically limited boundary layer can promote an enrichment of $\mathrm{NO}_{\mathrm{x}}$ in this layer, causing high troposheric $\mathrm{NO}_{2}$ columns.

Comparing the amplitude of the seasonal cycle of the tropospheric $\mathrm{NO}_{2}$ column densities in industrialized regions (eastern USA; similar for Europe, not shown) indicates an agreement within $20 \%$ (Fig. 3). Taking into account a $20 \%$ overestimation due to different sampling times (see above) agreement might be even better. In Fig. 3 additional results from model studies including a chemistry scheme which does not include higher hydrocarbons (ECHAM4.L39(DLR)/CHEM) are given (Lauer et al., 2002). Comparison shows that higher hydrocarbon chemistry in these regions mainly reduces atmospheric $\mathrm{NO}_{2}$ columns. In industrialized regions of the Northern Hemisphere deviations between modelled and observed values are higher in winter than in summer. This corresponds to a stronger reduced vertical mixing in the boundary layer in wintertime. On the other hand, the observations have a small sensitivity in the surface layer of the atmosphere due to physical reasons. This can serve as an explanation why 
January-ECHAM4/CBM

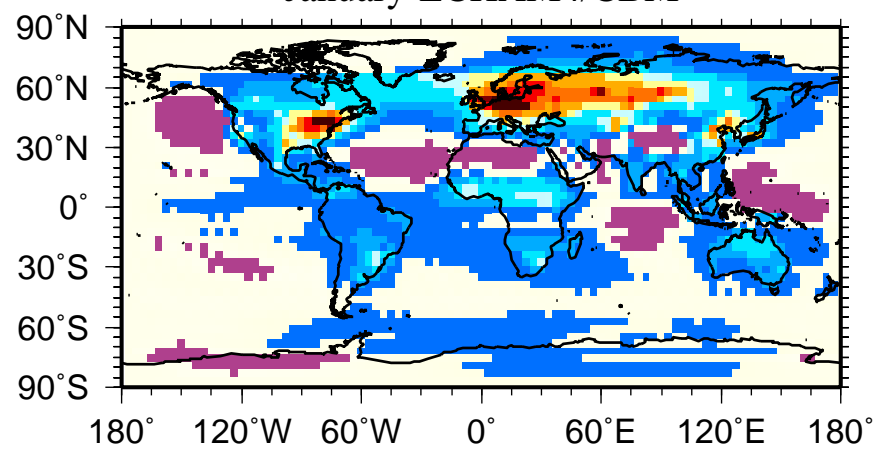

July-ECHAM4/CBM

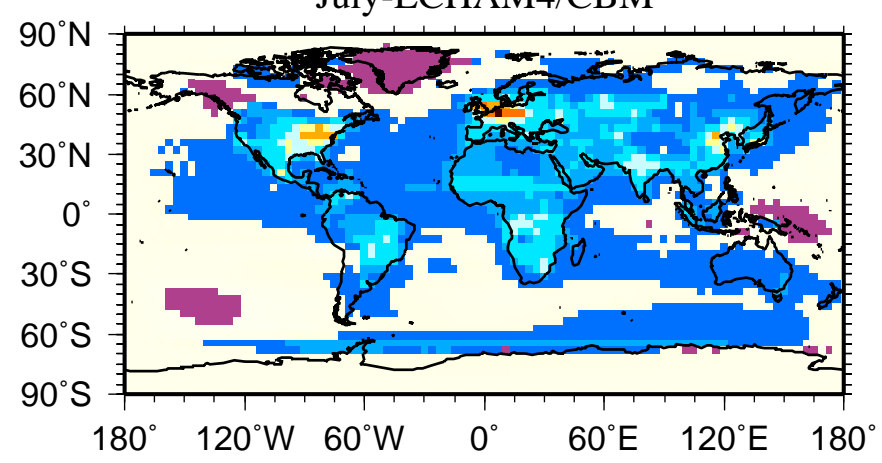

January-GOME96-00

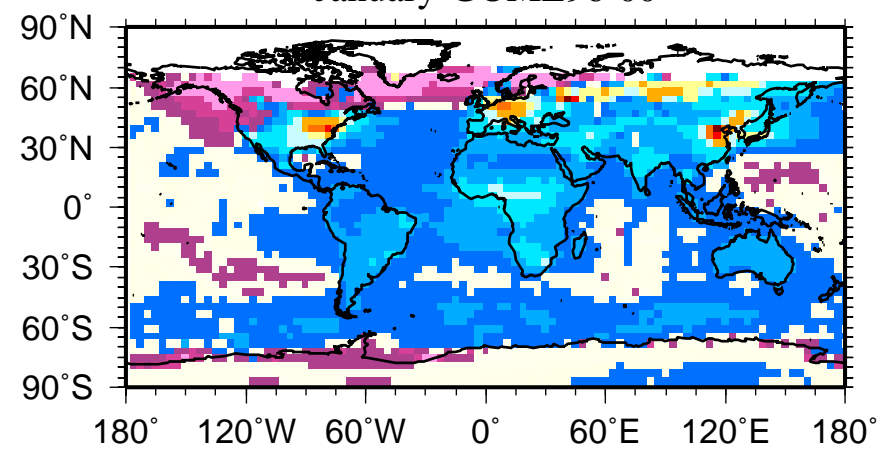

July-GOME96-00

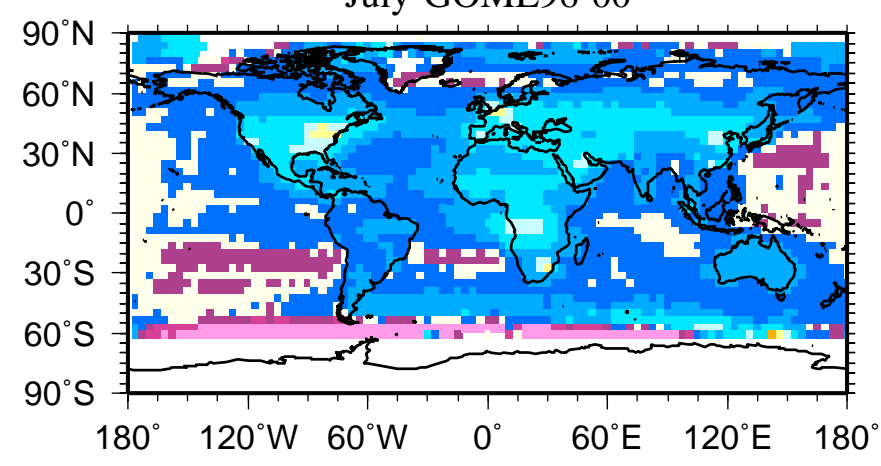

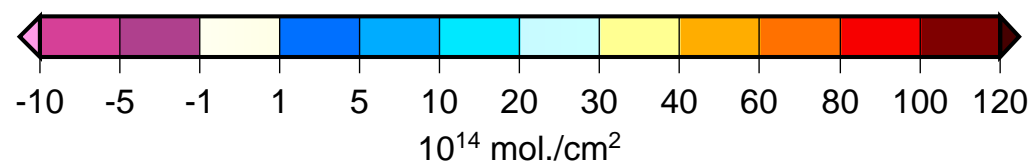

Fig. 2. Tropospheric $\mathrm{NO}_{2}$ columns $\left[10^{14} \mathrm{~mol} . \mathrm{cm}^{-2}\right]$ derived from GOME satellite data (right) (Richter and Burrows, 2002) and ECHAM4/CBM model simulations (left) for January (top) and July (bottom).

modelled data are higher than observed values. Additionally, clouds in wintertime prevent observations with the satellite instrument, which causes a sparse data base for northern hemispheric winter (December and January) and can cause a systematic bias of measurements. Deviations between observed and modelled $\mathrm{NO}_{2}$ columns amount to values between $15 \%$ and $30 \%$. Deviations of more than $50 \%$ are only found in remote regions with column densities of $\mathrm{NO}_{2}$ below $10 \times 10^{14}$ mol. $\mathrm{cm}^{-2}$ (Fig. 3, third row), where small concentrations of tropospheric $\mathrm{NO}_{2}$ in the reference sector influence the determined small tropospheric $\mathrm{NO}_{2}$-columns considerably. Therefore within these model regions, TEM can not be applied reliably in order to deduce $\mathrm{NO}_{2}$ tropospheric columns.

The preceeding comparison shows that the ECHAM4/CBM is able to reproduce the general pattern of the global $\mathrm{NO}_{2}$ column density distribution calculated with the TEM within regions where the reference sector does show no tropospheric influence ("clean air"). However absolute maximum values in industrialized areas (high $\mathrm{NO}_{\mathrm{x}}$-regions) show a tendency of higher values in the model than in observations. Due to non-linear photochemistry this would cause a lower estimate of ozone productivity of $\mathrm{NO}_{\mathrm{x}}$ emissions.

\section{Results}

\subsection{Impact of total road traffic emissions}

The changes in zonal monthly mean concentrations (CO, $\mathrm{NO}_{\mathrm{x}}$, alkanes, ozone) due to total road traffic emissions are presented in Fig. 4 for January and July (difference between the simulations No_rt and CTR90). Road traffic contributes to atmospheric carbon monoxide concentrations in the free troposphere of the summertime northern extratropics by more than $12 \%$ (Fig. 4, first row) or $10 \mathrm{ppb}$ (not shown). In January, contributions of more than $24 \%(20 \mathrm{ppb})$ are reached in the Northern Hemisphere due to a longer chemical lifetime (less photolysis in winter). In the southern extratropics relative contributions in the free troposphere are lower than in the northern extratropics due to smaller road traffic emissions in southern latitudes. Relative contributions 

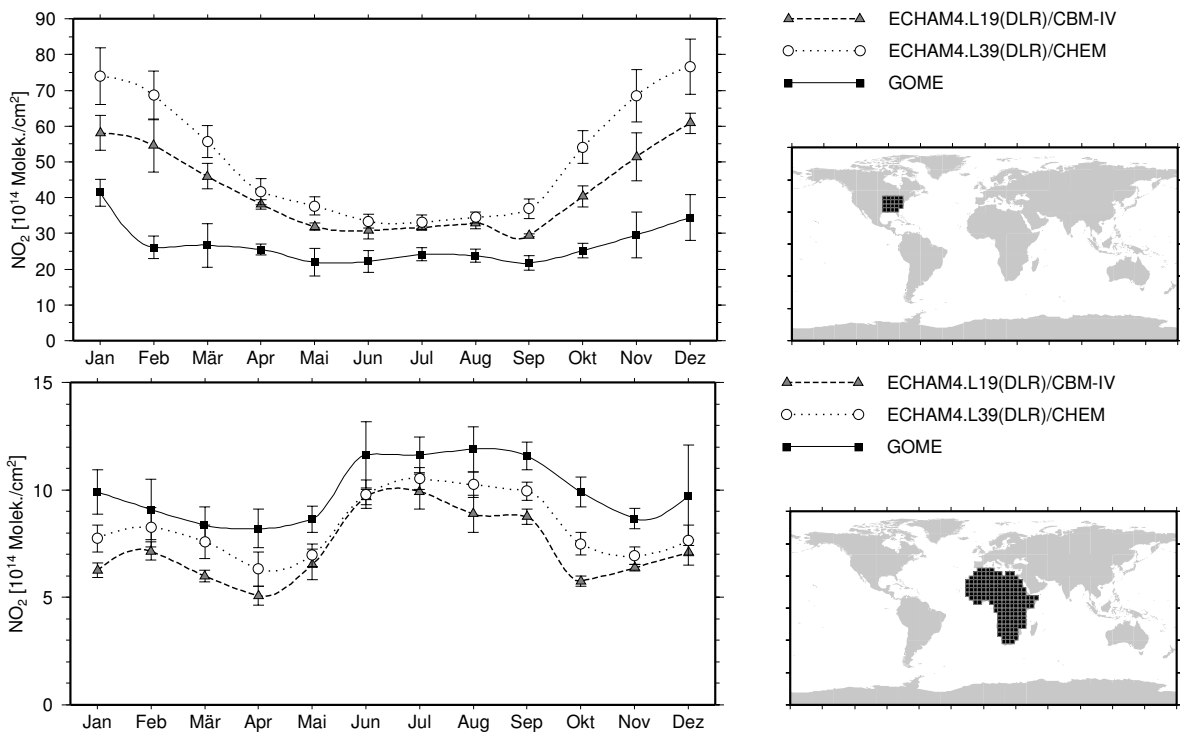

$\Delta----\Delta \quad$ ECHAM4.L19(DLR)/CBM-IV

O....... ECHAM4.L39(DLR)/CHEM

$\longrightarrow$ GOME
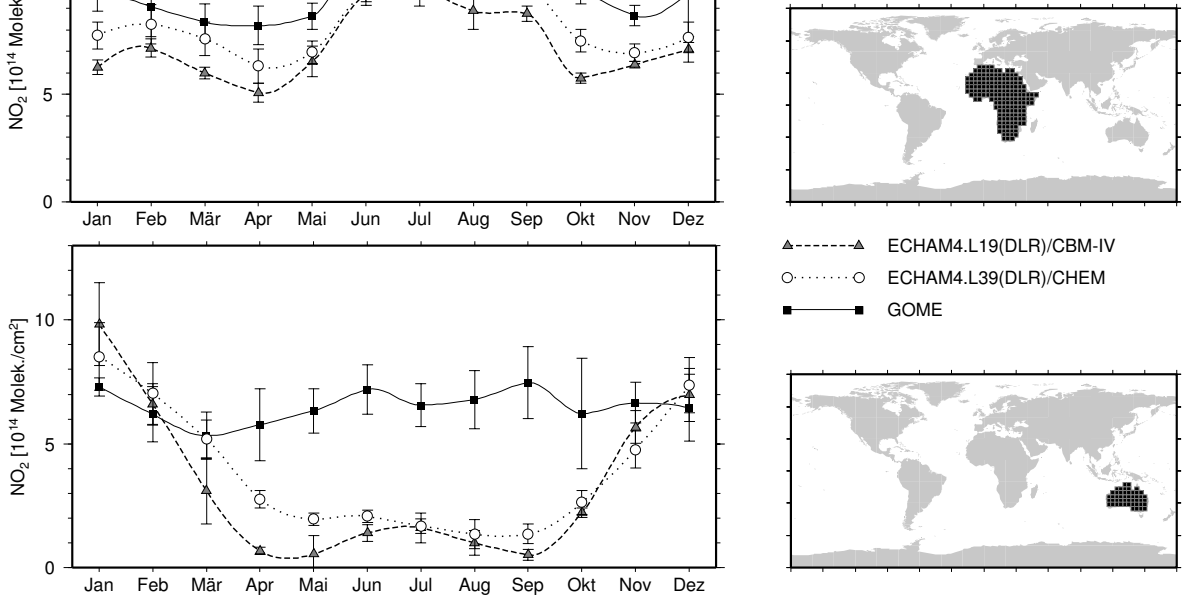

$\triangle-----\Delta \quad$ ECHAM4.L19(DLR)/CBM-IV

O.......

$\because$ GOME

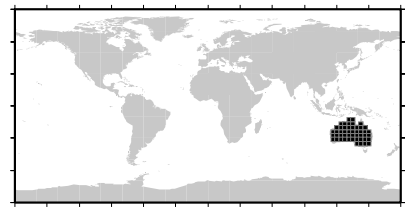

Fig. 3. Regional tropospheric $\mathrm{NO}_{2}$-columns derived from GOME satellite data (Richter and Burrows, 2002) and ECHAM4 model simulations (in $10^{14} \mathrm{~mol} . \mathrm{cm}^{-2}$ ). The respective geographic region for averaging is indicated in black: eastern USA, Africa and Australia.

amount to less than $8 \%(5 \mathrm{ppb})$ in January (summer) and to less than $12 \%(10 \mathrm{ppb})$ in July (winter). The highest values occur in source regions, with maximum contributions to atmospheric CO in January in the Northern Hemisphere near the surface (up to $32 \%$ or $100 \mathrm{ppb}$ ).

Road traffic emissions contribute to atmospheric $\mathrm{NO}_{\mathrm{x}}$ (Fig. 4, 2nd row) by a similar order of magnitude as to $\mathrm{CO}$, ranging from $8 \%$ to $24 \%$ in the extratropics ( 1 ppt to $200 \mathrm{ppt}$ ), depending on altitude and season. However, the impact of $\mathrm{NO}_{\mathrm{x}}$ emissions compared to $\mathrm{CO}$ is much more confined to the vicinity of the source regions as the atmospheric lifetime of $\mathrm{NO}_{\mathrm{x}}$ is about one order of magnitude shorter than the lifetime of CO. In midlatitudes near the surface, contributions up to $32 \%$ are calculated (10 ppt NH, $200 \mathrm{ppt} \mathrm{SH}$ ), whereas in the free troposphere values around $12 \%$ are found (1-10 ppt). Beside these high contributions in midlatitudes, relative contributions of more than $50 \%$ appear in arctic regions (2 ppt). These relative contributions correspond to absolute contributions in arctic regions of about 2 ppt $\mathrm{NO}_{\mathrm{x}}$. This effect is particularly pronounced in winter (January). As will be shown in the sensitivity studies in the next section these high contributions are caused by NMHC road traffic emissions leading to enhanced formation of PAN. PAN is then transported throughout the hemisphere and decomposes in subsidence regions (Sect. 4.3). This represents an indirect transport of $\mathrm{NO}_{\mathrm{x}}$ from road traffic.

The impact of road traffic emissions on atmospheric concentration of alkanes (Fig. 4, 3rd row) reaches relative contributions of more than 50\% (up to 5 ppt January, 2 ppt July). Alkanes are selected as a representative for a NMHC with comparatively long chemical lifetime. These high relative contributions show that road traffic represents one of the major emitters of alkanes, for which anthropogenic sources dominate. In the Northern Hemisphere, again relative contributions are higher in winter than in summer (indicated by larger atmospheric regions with contributions above $50 \%$ ), due to longer chemical lifetimes in winter. In the Southern Hemisphere (SH) relative contributions show an opposite seasonality with higher contributions in summer than in winter (Fig. 4), although absolute contributions are lower in summer than in winter (Matthes, 2003). The opposite seasonality in relative contributions is caused by strong seasonality of natural emissions, which compensates for the seasonal cycle of NMHC lifetimes and $\mathrm{OH}$ concentrations, respectively.

Characteristic differences in the pattern of the relative contributions of road traffic emissions to the distribution of 

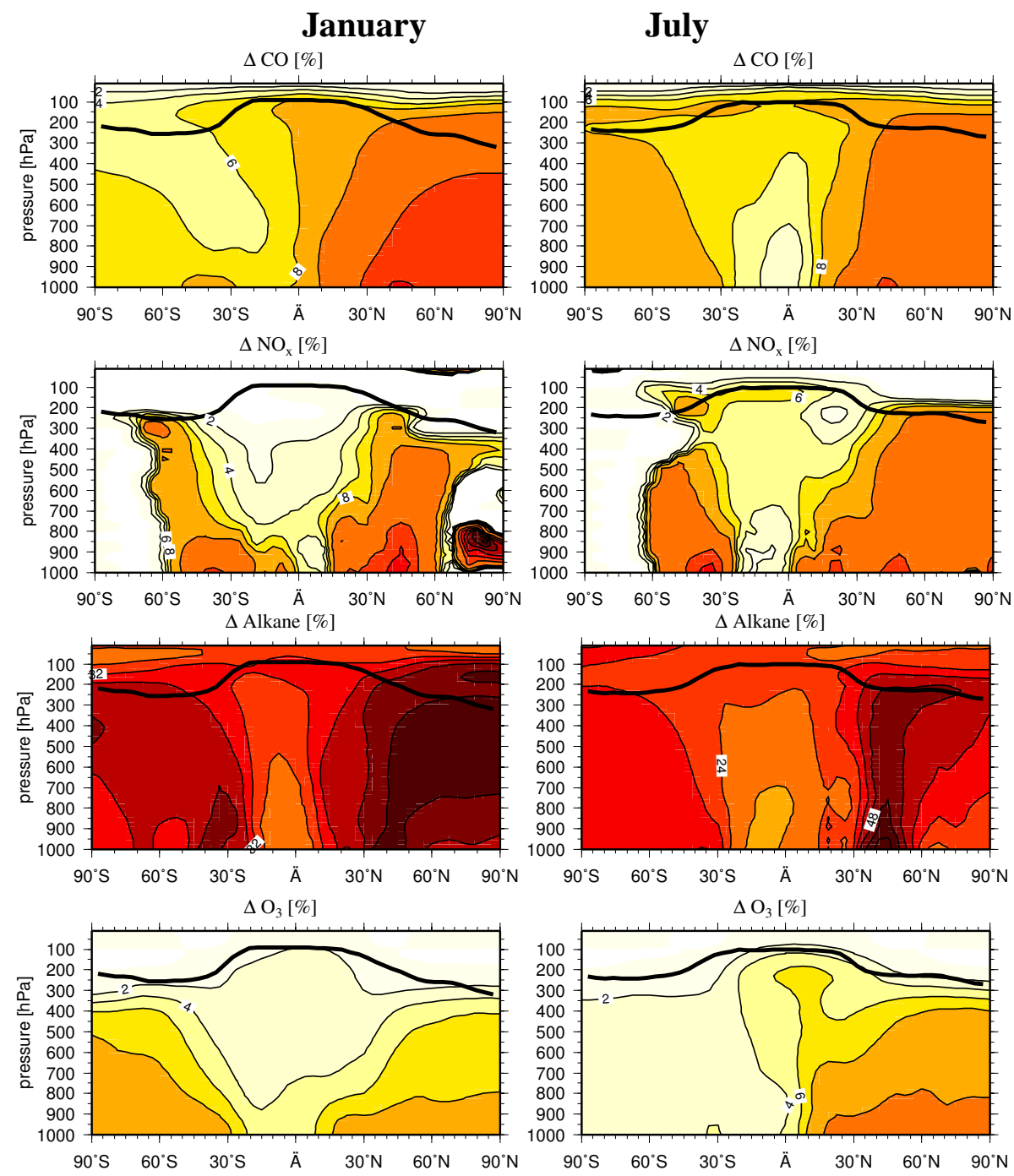

Fig. 4. Relative contribution of road traffic emissions to atmospheric $\mathrm{CO}, \mathrm{NO}_{\mathrm{x}}, \mathrm{NMHCs}$ and $\mathrm{O}_{3}$ zonally averaged distributions (in $\%$ ). Isolines are 2, 4, 6, 8, 12, 24, 32, 48, 56\%.

atmospheric ozone (Fig. 4, bottom) can be found between January and July. Its seasonality shows a pattern opposite to the primary species (see above), with maximum ozone contributions occurring in summer and minimum values in winter. While ozone formation is increased by an enhanced abundance of its precursors, not only the concentration of precursors is of importance, but also the photochemical activity which has its maximum in summer. In the summer hemispheres, relative contributions to the atmospheric burden of ozone of more than $12 \%(\mathrm{NH}$, up to $5 \mathrm{ppb}$ ) and $8 \%$ ( $\mathrm{SH}$, up to $1 \mathrm{ppb}$ ) from road traffic induced ozone occur. In winter hemispheres relative contributions are lower by a factor between 1.5 and 2 in the $\mathrm{NH}$ and of about 3 in the SH.

Road traffic induced ozone increase in the SH in summer (January) is only a factor of 5 smaller than in the $\mathrm{NH}$, although emissions are lower by a factor of roughly 20 . Reason for this comparatively high relative ozone contribution in the
Southern Hemisphere is the low background concentrations of trace gases, especially nitrogen oxides. As productivity of ozone production decreases with increasing $\mathrm{NO}_{\mathrm{x}}$ concentrations (Liu et al., 1980, 1987) $\mathrm{NO}_{\mathrm{x}}$ emissions from road traffic are much more effective when emitted in the Southern Hemisphere. In the Northern Hemisphere ozone production takes place at high $\mathrm{NO}_{\mathrm{x}}$ concentrations, often in the saturation regime. Thus a further $\mathrm{NO}_{\mathrm{x}}$ increase only leads to a weak increase of the production rate or even to a decrease.

For comparison of our results to those presented by Granier and Brasseur (2003), the horizontal distribution of relative contributions to surface ozone is shown (Fig. 5, left). In July, an overall increase in surface ozone due to total road traffic emissions between $8 \%$ and $15 \%(2-5 \mathrm{ppt})$ in nonsource regions in northern extratropics (e.g. North Atlantic, North Pacific) and higher contributions of up to little more than $16 \%$ (10 ppt) in source regions (e.g. central Europe, 

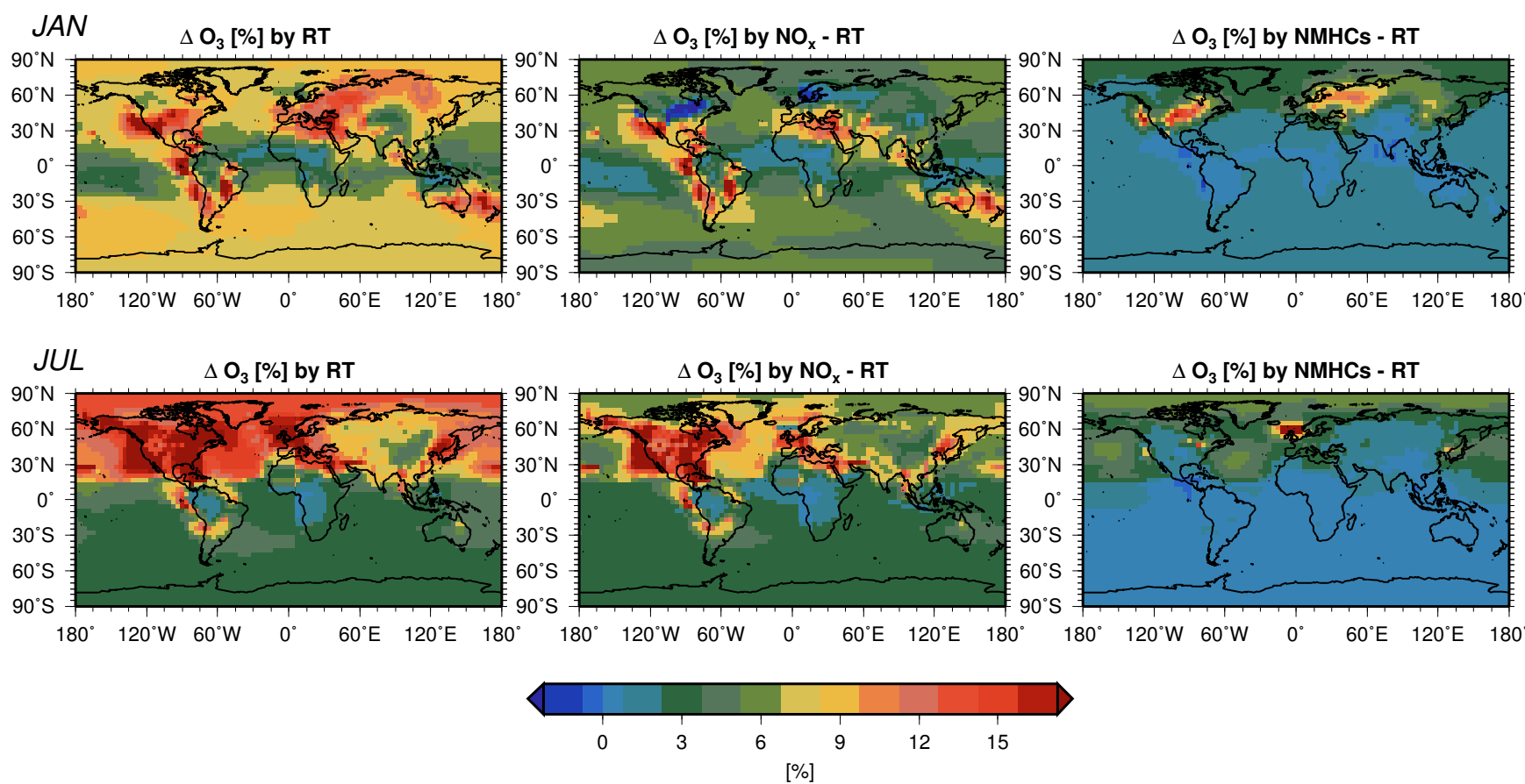

Fig. 5. Relative contributions [\%] of total and individual road traffic emissions to the surface ozone distribution in January (upper row) and July (lower row); total emissions (left), $\mathrm{NO}_{\mathrm{x}}$ only (middle) and $\mathrm{NMHC}$ only (right).

USA, Japan) can be found (lower panel). In source regions, these results are comparable to the findings of Granier and Brasseur (2003), who calculated about the same relative contribution (10\% to $15 \%)$. However, a remarkable difference occurs in non-source regions where their calculation showed lower relative contributions of 6 to $9 \%$, only. Looking at the impact of individual road traffic emission compounds (see Fig. 5, middle and right), the origin of this difference can be attributed to neglecting of NMHC road traffic emissions. The impact of $\mathrm{NO}_{\mathrm{x}}$ emissions on ozone is strongly confined within source regions, while the impact of NMHC emissions is visible in remote areas also. These typical different patterns lead us to the conclusion, that main origin of differences between our results and Granier and Brasseur (2003) are attributed to NMHC emissions from road traffic which they did not consider. In the Southern Hemisphere, relative contributions remain lower than on the Northern Hemisphere, with values of more than $8 \%$ being calculated only in July in continental source regions and more than $4 \%$ contribution only in certain outflow regions (e.g. Pacific ocean, east coast of South America, tropical pacific), which is comparable to the findings of Granier and Brasseur (2003).

As Granier and Brasseur (2003) give only values for July, no direct comparison is possible for January. By comparing the impact of total road traffic emissions with the impact of $\mathrm{NO}_{\mathrm{x}}$ emission only (Fig. 5), the significant role of NMHCs becomes again obvious. In the Northern Hemisphere in January, the relative contribution of total road traffic emissions remain much lower in source regions compared to July with only more than $8 \%$, sometimes even less due to weaker photochemistry (as mentioned before). Relative contributions of more than $16 \%$ are only found in a few locations, e.g. southern USA, Arabian Peninsular. In January however, the relative contributions in southern latitudes are higher due to enhanced photochemistry (summer) and low background concentrations (see discussion above). There, relative contributions of more than $16 \%$ are found in industrialized centres (e.g. South America, New Zealand). Over large parts of southern hemispheric extratropic oceans relative contributions of more than $8 \%$ are simulated. This emphasises the considerable long-range impact of road traffic emissions on ozone in remote regions.

\subsection{Importance of individual emissions for ozone}

To determine the impact of individual components from road traffic emissions we will discuss now separate sensitivity experiments for $\mathrm{NO}_{\mathrm{x}}, \mathrm{CO}$ and $\mathrm{NMHC}$ emissions only (Table 2). This approach has been chosen to account for non-linearities. This non-linearity appears as the summed impact calculated by these individual simulations is i.g. less than 10 percent higher than the simultaneous impact from these components on ozone.

In Fig. 5, the individual contributions of both $\mathrm{NO}_{\mathrm{x}}$ (middle) and NMHCs emissions (right) together with the total impact of road traffic to surface ozone are shown. Maximum contributions to atmospheric ozone from road traffic 

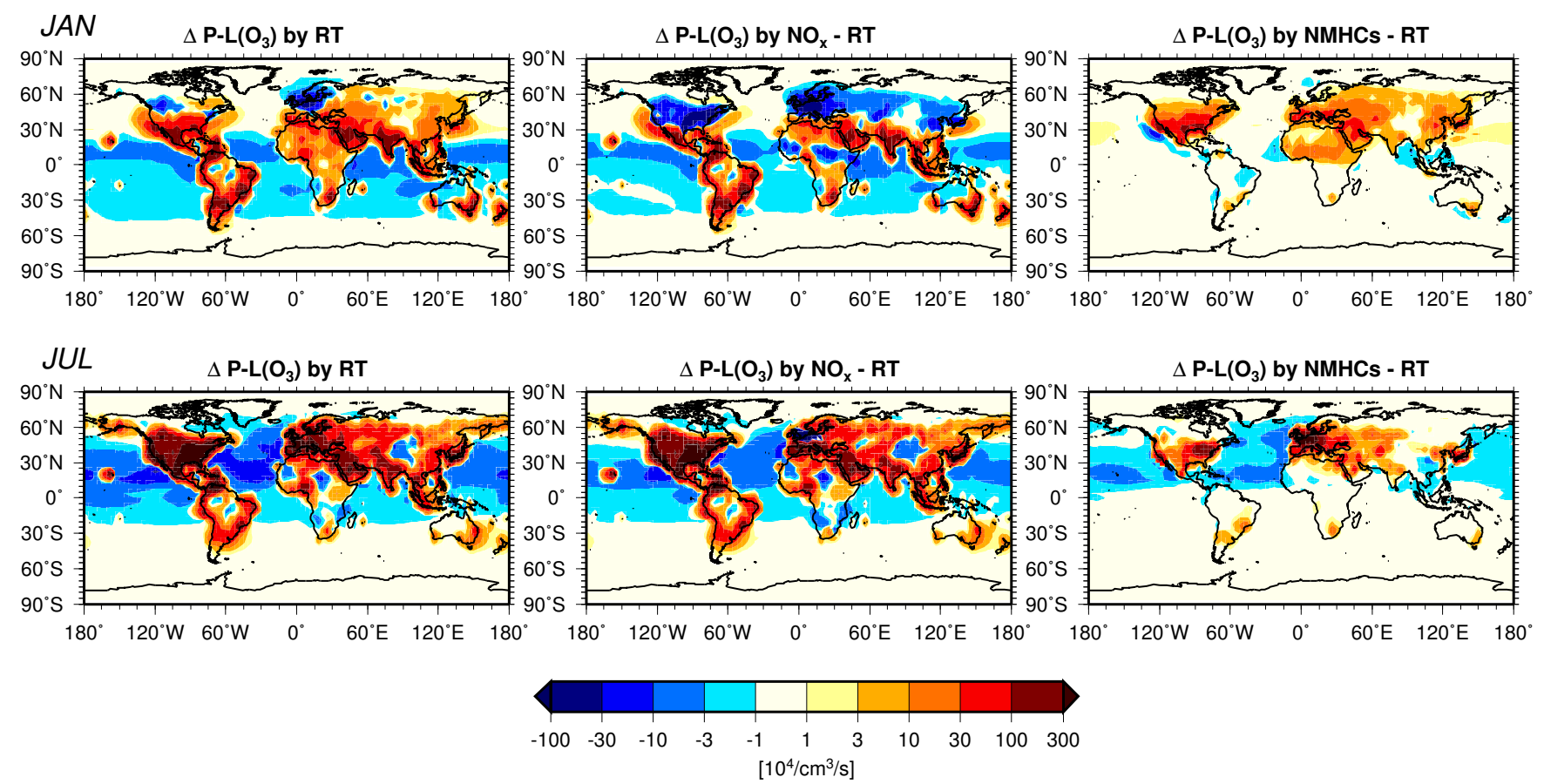

Fig. 6. Contributions [\%] of individual road traffic emissions - $\mathrm{NO}_{\mathrm{x}}$ (left), $\mathrm{NMHCs}$ (middle)) and $\mathrm{CO}$ (right) to distribution of net ozone production.

$\mathrm{NO}_{\mathrm{x}}$ emissions are found in summer in source regions and downwind regions (about 15\%), especially over North America and Europe. In January, road traffic $\mathrm{NO}_{\mathrm{x}}$ emissions even lead to ozone decrease in strongly confined areas of source regions, caused by a dominating decrease of ozone productivity of $\mathrm{NO}_{\mathrm{x}}$ with increasing $\mathrm{NO}_{\mathrm{x}}$ concentrations.

NMHCs (like CO) act as a source for the hydroperoxyl radical (R5)

$\mathrm{RH}+\mathrm{OH} \rightarrow \mathrm{R}+\mathrm{HO}_{2}$

thereby influencing Reactions (R3) and (R4). In these strongly confined areas, road traffic NMHC emission contribute in July about $12 \%$ to ozone. In other Northern Hemisphere regions, especially in higher latitudes, an ozone increase by around $4 \%$ is found, with higher contributions (up to 6\%) in remote areas (e.g. oceans, Arctic) than in sources regions (approximately 2\%), other than the hot spots (e.g. parts of Europe and USA).

To better understand the ozone changes Fig. 6 shows changes in net ozone production rate. $\mathrm{NO}_{\mathrm{x}}$ road traffic emissions enhance ozone production and ozone loss in winter and summer. In source regions this leads to a positive net ozone production in summer. In winter a transition is found at around $30-50 \mathrm{~N}$ which ranges from positive values at lower latitudes to negative values at higher latitudes. In winter NMHC emissions lead to a reduced production and a reduced loss of ozone resulting in an increased net ozone production (Fig. 6). In summer, this pattern is seen in a smaller area, since a competing mechanism, caused by the long-range transport of PAN is enhancing both ozone production and loss. This decrease in ozone loss results either from lower ozone concentrations or lower $\mathrm{NO}_{\mathrm{x}}$ concentrations, since $\mathrm{OH}$ and $\mathrm{HO}_{2}$ are increasing.

The impact of $\mathrm{CO}$ emissions from road traffic on atmospheric ozone is not shown because it is about a factor 10 smaller than that of $\mathrm{NO}_{\mathrm{x}}$ emissions in both January and July.

Figure 7 displays the zonal mean ozone change due to individual emission components from road traffic, in order to quantify the different role of road traffic $\mathrm{NO}_{\mathrm{x}}$ and $\mathrm{NMHC}$ emissions in the free troposphere (for totals see Fig. 4, bottom). The effect of both, total emissions and $\mathrm{NO}_{\mathrm{x}}$ emissions, is strongest in latitudes where the main source regions of road traffic emissions are located $\left(15^{\circ} \mathrm{N}-60^{\circ} \mathrm{N}\right)$. In July, $\mathrm{NO}_{\mathrm{x}}$ emissions in northern hemispheric source regions contribute by more than $10 \%$ to the zonally averaged near surface ozone. At $800 \mathrm{hPa}$ and below, a relative contribution of more than $8 \%$ can be attributed to road transport $\mathrm{NO}_{\mathrm{x}}$ emissions in these latitudes. More regional considerations show (see Sect. 4.4), the atmospheric distributions in these altitudes are predominantly influenced by regional emissions. This is consistent with the short atmospheric lifetime of $\mathrm{NO}_{\mathrm{x}}$ of only several days. At higher altitudes up to $300 \mathrm{hPa}$, relative contributions of global road traffic $\mathrm{NO}_{\mathrm{x}}$ emissions of more than $4 \%$ can be noticed in July. Generally, about $70 \%$ of the total ozone increases is caused by $\mathrm{NO}_{\mathrm{x}}$ emissions from road transport at latitudes, where the main sources are 
located, and in the free troposphere. Meridional gradients are distinct for $\mathrm{NO}_{\mathrm{x}}$ related ozone increase especially in July, reflecting fast photochemistry and related short atmospheric lifetime.

In July, NMHC emissions contribute considerably less than $\mathrm{NO}_{\mathrm{x}}$ emissions to ozone in those source latitudes $\left(15^{\circ} \mathrm{N}-60^{\circ} \mathrm{N}\right)$ with only about $3 \%$ (Fig. 7 , middle row). Ozone contributions, of about $6 \%$, are found in arctic regions. In these remote regions the effect due to NMHC emissions has about the same strength as due to $\mathrm{NO}_{\mathrm{x}}$ emissions (Fig. 7, upper row), which is consistent with above discussed contributions to surface ozone. One mechanism for the longrange impact of NMHC emissions from road transport is additional PAN-formation (see Sect. 4.3). In January, road traffic NMHC emissions contribute strongest to zonally averaged ozone in source latitudes with more than $4 \%$ relative contribution, by inhibiting ozone titration, and more than $2 \%$ in northern hemispheric extratropics, but outside the main source regions. Again the strong contribution in arctic latitudes is noteworthy.

As mentioned above, the impact of $\mathrm{CO}$ emissions from road traffic on atmospheric ozone is about a factor of 10 smaller than that of $\mathrm{NO}_{\mathrm{x}}$ emissions in both January and July. Relative contributions of $1 \%$ and $2 \%$ can be found in latitudes north of $30^{\circ} \mathrm{N}$ below $400 \mathrm{hPa}$, elsewhere it is even less.

To sum up these results it can be noted that the total impact of road traffic emissions $\left(\mathrm{NO}_{\mathrm{x}}, \mathrm{CO}, \mathrm{NMHCs}\right)$ is dominated by the impact of $\mathrm{NO}_{\mathrm{x}}$ emissions in source regions and while it is substantially influenced by the impact of NMHC (and $\mathrm{CO}$ ) emissions in non-source regions. This importance of NMHC emissions (and partly $\mathrm{CO}$ ) became obvious from the comparison between the impact due to exclusive consideration of $\mathrm{NO}_{\mathrm{x}}$ and the impact by consideration of all three emission species together $\left(\mathrm{NO}_{\mathrm{x}}, \mathrm{NMHCs}, \mathrm{CO}\right)$. Particularly, relative contributions of road traffic emissions in remote regions increase, e.g. in arctic regions in July, from about $8 \%$ to about $15 \%$. As will be shown in the next sub-section (4.3) the mechanism for long-range impact of NMHC emissions is transport of additionally formed PAN, which acts as a temporal reservoir for $\mathrm{NO}_{\mathrm{x}}$ and allows an indirect long-range transport of $\mathrm{NO}_{\mathrm{x}}$ from source regions.

When comparing our separate sensitivity experiments for $\mathrm{NO}_{\mathrm{x}}$ and $\mathrm{CO}$ emissions only (No_NOx, No_CO) with total road traffic impact $\left(\mathrm{NO}_{\mathrm{x}}\right.$ and $\mathrm{CO}$ only) given by Granier and Brasseur (2003), respective results for impact on ozone largely agree. But as Granier and Brasseur (2003) did not account for road traffic NMHC emissions, they underestimated the total impact of road traffic emissions on ozone. The sensitivity experiment for NMHC emissions (No_NMHC) revealed that in remote areas NMHCs act as an additonal source for road traffic induced ozone. In these areas ozone is formed due to long-range transport of PAN from NMHC road traffic emissions.
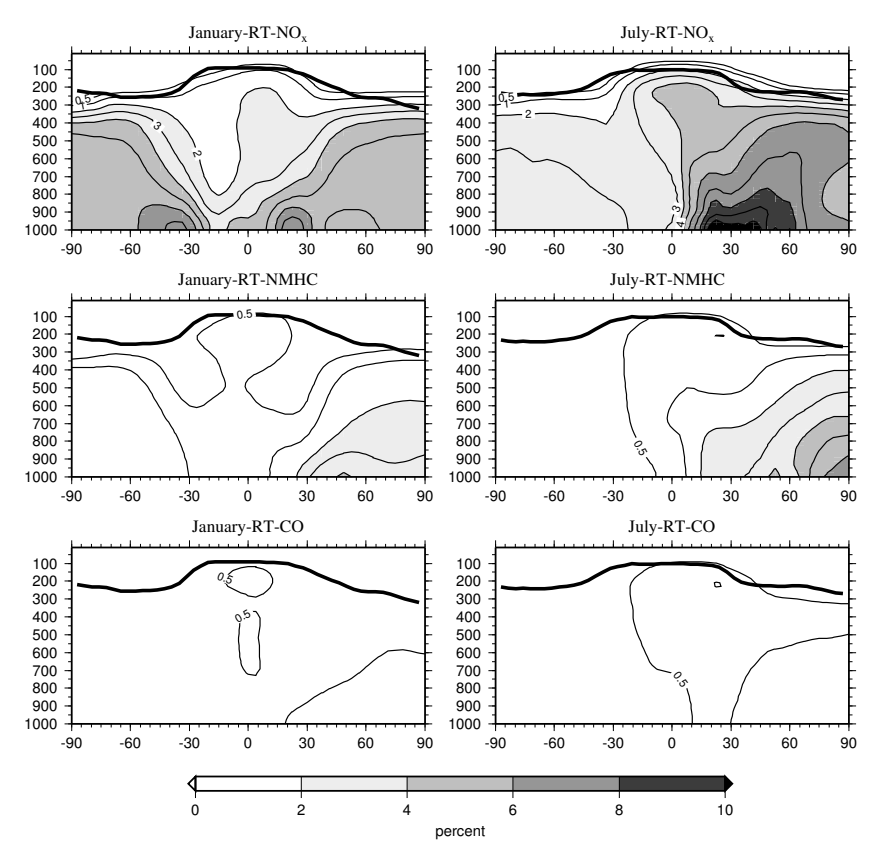

Fig. 7. Contributions [\%] of individual road traffic emissions $\mathrm{NO}_{\mathrm{x}}$ (upper), NMHCs (middle)) and $\mathrm{CO}$ (lower) to atmospheric distribution of ozone. Isolines are equidistant with $1 \%$ difference, plus one additional line for $0.5 \%$.

\subsection{Role of road traffic NMHC emissions in PAN forma- tion and long-range transport into Arctic latitudes}

We have mentioned several times the importance of PAN as reservoir species for transferring $\mathrm{NO}_{\mathrm{x}}$ emissions to regions far away from the sources. NMHC emissions from road traffic form PAN together with atmospheric $\mathrm{NO}_{\mathrm{x}}$ in source regions. PAN is thermally stable at low temperatures and can be transported over long distances to remote regions. Subsidence causes an adiabatic heating, causing PAN to decay thermally and leads to additional $\mathrm{NO}_{\mathrm{x}}$. In low- $\mathrm{NO}_{\mathrm{x}}$ regions this $\mathrm{NO}_{\mathrm{x}}$ leads to ozone production and as a consequence causes high relative contributions of road traffic emissions to zonally averaged ozone concentrations in arctic regions of more than 6\% (Fig. 7, middle row).

As one example for remote regions, the regionally averaged concentration changes of PAN due to road traffic emissions are shown in Fig. 8 in both northern hemispheric midlatitudes and arctic regions. A strong PAN enhancement is indicated due to all road traffic emissions (solid lines), a slightly weaker due to NMHC emissions only (dashed lines) and clearly weaker due to $\mathrm{NO}_{\mathrm{x}}$ emissions only (dotted lines). In spring, in arctic (PN) and mid-latitudes (NHE), total road traffic emissions are responsible for a PAN enhancement of $75 \mathrm{ppt}$ (solid line, regional average north of $68^{\circ}$ below $550 \mathrm{hPa}$ ), whereas NMHC emissions alone cause in arctic latitudes an increase of about $65 \mathrm{ppt}$ (dotted line). On the other hand, $\mathrm{NO}_{\mathrm{x}}$ emissions alone cause a PAN increase of 


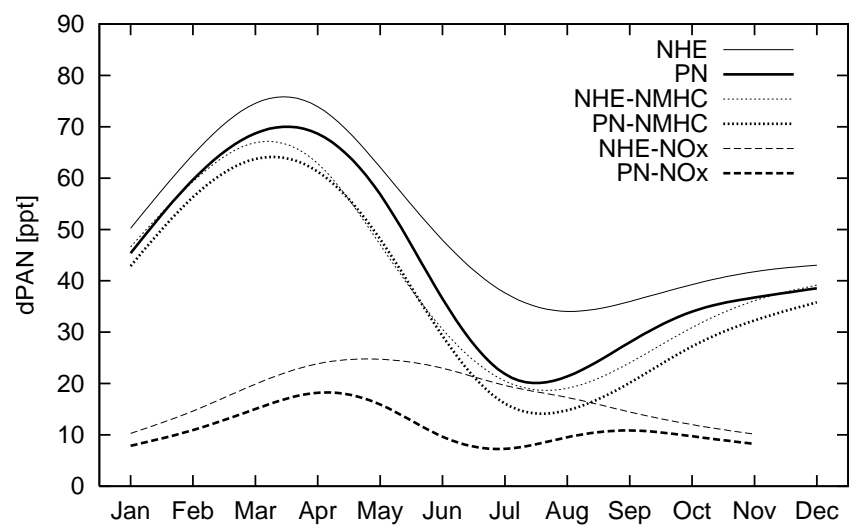

Fig. 8. Individual contributions of road traffic emissions to PAN in two regions: (1) mid-latitudes near the surface $\left(\mathrm{NHE} ; 30^{\circ} \mathrm{N}-\right.$ $60^{\circ} \mathrm{N}$, below $750 \mathrm{hPa}$ ) and (2) arctic regions $\left(\mathrm{PN} ; 68^{\circ} \mathrm{N}-90^{\circ} \mathrm{N}\right.$, below $550 \mathrm{hPa}$ ); total (solid), $\mathrm{NMHCs}$ (dotted), $\mathrm{NO}_{\mathrm{x}}$ (dashed)).

only about $20 \mathrm{ppt}$ (dashed line). In the following we use these results from individual components scenarios for deducing an estimate on the relative importance of individual species. Hereby it has to be noted, that the sum of individual impacts overestimates the total impact by less than $10 \%$. NMHC emissions are responsible for about $90 \%$ of PAN enhancement in winter and springtime in arctic latitudes (PN). Due to higher atmospheric temperatures in spring and summer, the absolute size of this effects decreases from April on. In summer absolute values only amount to about $20 \mathrm{ppt}$ contribution due to gaseous road traffic emissions $\left(\mathrm{NO}_{\mathrm{x}}, \mathrm{NMHCs}\right.$ and $\mathrm{CO}$ ). Nevertheless NMHCs still represent the major contributor with about 50\%. Hence Fig. 8 illustrates that road traffic NMHC-emissions are crucial for the formation and long-range transport of PAN which then causes ozone contribution of road traffic in remote regions.

The synthesis of the role for the impact of all three individual emission components is illustrated in Fig. 9 for the three different regions: source regions (e.g. Europe), transport regions (free troposphere) and remote regions (e.g. Atlantic ocean, Arctic). The scheme includes the impact on the Hydroxylradical. In source regions, $\mathrm{NO}_{\mathrm{x}}$ emissions from road traffic (red colored) are mainly important for ozone production depending on season. This causes a decrease in winter (January) and an increase in summer (July) of the concentrations of the atmospheric hydroxyl radical. In strongly confined regions (high- $\mathrm{NO}_{\mathrm{x}}$ ) increasing $\mathrm{HO}_{\mathrm{x}}$ can strongly reduce ozone productivity and overcompensate the $\mathrm{NO}_{\mathrm{x}}$ increase due to road traffic emissions, causing a decrease of ozone. In source regions, generally NMHC emissions convert additional $\mathrm{OH}$ into $\mathrm{HO}_{2}$ during their oxidation (R5). Radicals formed during the oxidation process produce more $\mathrm{HO}_{\mathrm{x}}$ than they consume within their initial reaction. The enhanced $\mathrm{HO}_{\mathrm{x}}$ increases ozone productivity of nitrogen oxides. In winter $\mathrm{HO}_{\mathrm{x}}$ increases so strongly in source regions of the

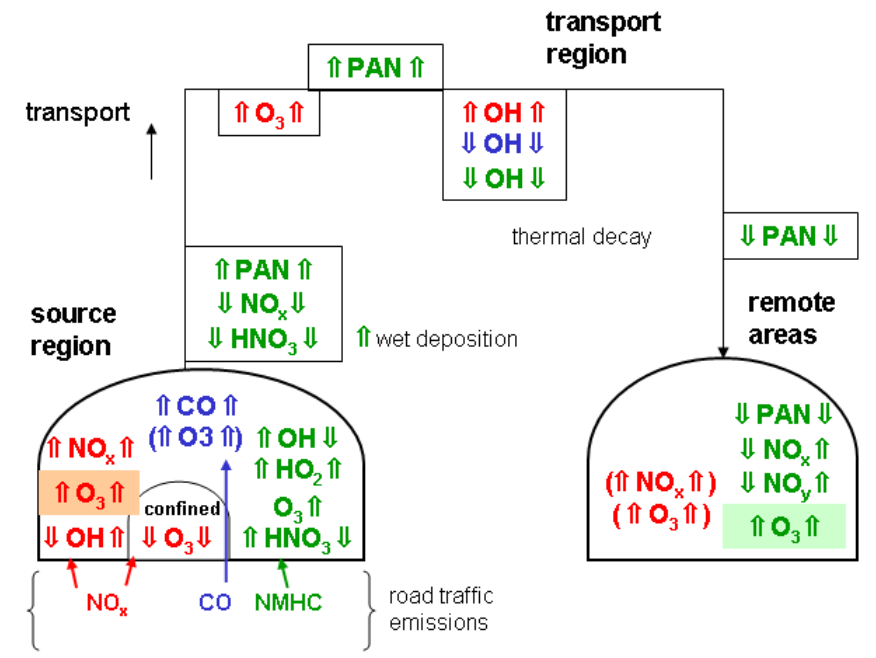

Fig. 9. Scheme illustrating the impact of individual components of road traffic emissions on atmospheric composition: $\mathrm{NO}_{\mathrm{x}}$ (red), $\mathrm{CO}$ (blue), NMHCs (green). An arrow up indicates increase, down a decrease; the arrows on the left of the specie describe the change in winter, those on the right the change in summer. Weak processes are in parenthesis, major processes are highlighted with a coloured background.

Northern Hemisphere that - in spite of a relative decrease of $\mathrm{HO}_{\mathrm{x}}-\mathrm{OH}$ increases. The increased $\mathrm{OH}$ concentrations form an enhanced sink for $\mathrm{NO}_{\mathrm{x}}$ and more $\mathrm{HNO}_{3}$ is produced. In transport regions PAN concentrations are enhanced and $\mathrm{NO}_{\mathrm{x}}$ are reduced due to NMHC emissions from road traffic. On the other hand, $\mathrm{HNO}_{3}$ concentrations are reduced due to wet deposition in transported air masses. During subsidence of air masses PAN decomposes thermally and the PAN concentration decreases. In remote regions the above mentioned impact of NMHCs makes these species responsible for a major ozone increase.

Figure 5 showed that ozone destruction due to road traffic $\mathrm{NO}_{\mathrm{x}}$ emissions occurs in the industrialized areas in Central Europe and North America. Since NMHC road traffic emissions cause long-range transport of $\mathrm{NO}_{\mathrm{x}}$ (see above) the geographic origin of emissions is of primary interest. Therefore, we performed studies of regional road traffic emissions $\left(\mathrm{NO}_{\mathrm{x}}, \mathrm{NMHCs}, \mathrm{CO}\right)$ : USA only or Europe only (No_rtusa and No_rteur in Table 2), which will now be discussed.

\subsection{Impact of regional emissions from the USA and Europe}

The results of the USA and Europe related impact simulations are shown in Fig. 10. The meriodionally averaged, relative contributions to atmospheric ozone (Fig. 10, upper row) indicate that long-range transport occurs eastward. In the free troposphere (above $900 \mathrm{hPa}$ ) over the USA in midlatitudes, global road traffic contributes by about $8 \%$ (6 ppb), whereas emissions from the USA itself contribute more than $4 \%$ ( $3 \mathrm{ppb}$ ). In the free troposphere over the Atlantic, $4 \%-8 \%$ 
Mid-latitudes of Northern Hemisphere
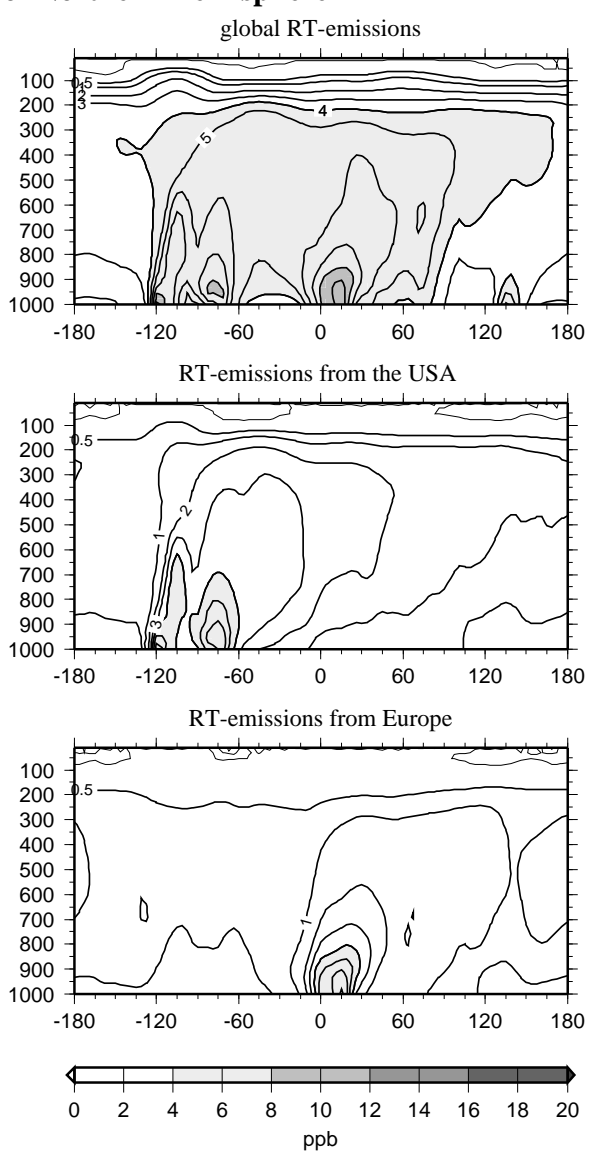

Northern tropics
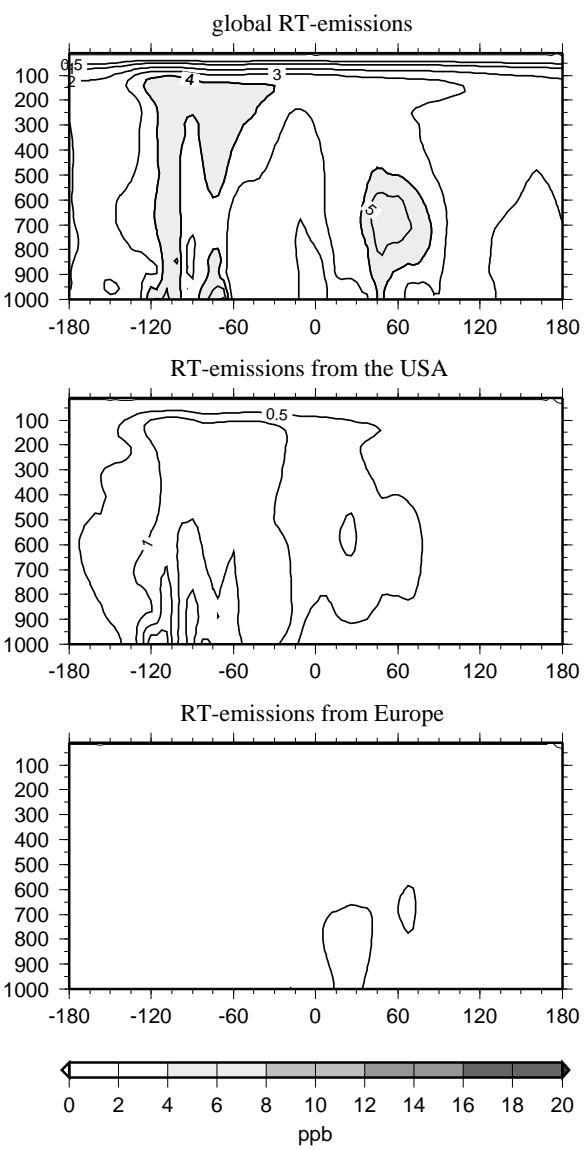

Fig. 10. Contributions [ppbv] of road traffic (RT) emissions to meridionally averaged ozone: global emissions (upper), emissions from the USA (middle) and emissions from Europe (lower) in July. Mid-latitudes denote meridionally averaging over $30^{\circ} \mathrm{N}-60^{\circ} \mathrm{N}$ and northern tropics over Equator $-30^{\circ} \mathrm{N}$; isolines distance $1 \mathrm{ppb}$, plus one additional at $.5 \mathrm{ppb}$.

$(2-4 \mathrm{ppb})$ of the ozone concentration has its origin in road traffic emissions in USA and about $2 \%$ (1 ppb) originates from Europe, out of a road traffic contribution from global road traffic emissions of $8 \%$ to $12 \%(4-5 \mathrm{ppb})$. In the free troposphere over Europe in midlatitudes, emissions from the USA still contribute by more than $3 \%$ ( $2 \mathrm{ppb})$, where the impact of global road traffic emissions amounts to $8 \%$ (5 ppb) $\left(700 \mathrm{hPa}-300 \mathrm{hPa} ; 30^{\circ} \mathrm{E}\right)$. and road traffic emissions from Europe contribute by up to $4 \%$ ( $2 \mathrm{ppb})$. Further east $\left(30^{\circ} \mathrm{E}-\right.$ $130^{\circ} \mathrm{E}$ ) in the free troposphere relative contributions from Europe and the USA have about the same size of $2 \%$ (1 ppb) here; global emissions contribute more (about $8 \%$ or $5 \mathrm{ppb}$ ). Over Asia, where global road traffic emissions contribute up to $8 \%$ ( $4 \mathrm{ppb}$ ) to mid-latitude ozone abundance a contribution of about $2 \%$ ( $1 \mathrm{ppb}$ ) due to road traffic emissions in the USA can be found (Fig. 10, middle row) whereas on the other hand, emissions from Europe contribute there about $2 \%(0.5 \mathrm{ppb})$. Results show that Europe and USA road traffic emissions can represent up to $50 \%$ of the global road traffic contribution to the ozone distribution in mid-latitudes in the free troposphere. Surface ozone concentrations are only significantly affected by long-range transport in remote areas.

In northern tropics (Fig. 10, right panels), global road traffic emissions contribute more than $8 \%$ (4 ppb) above the USA/Central America to atmospheric ozone. Road traffic in the USA represents with around $2 \%$ (1 ppb) only about a quarter of these total ozone contributions (up to $200 \mathrm{hPa}$ in tropical latitudes). European emissions from road traffic show a maximum relative contribution of $1 \%(0.5 \mathrm{ppb})$ around $30^{\circ} \mathrm{E}$ (Arabian Peninsular), clearly illustrating the minor importance of European road traffic emissions for the tropics. The sensitivity studies show the strong zonal transport of road traffic impact on ozone, and the much weaker meridional transport. The results are consistent with the findings of Wild and Akimoto (2001), who studied the intercontinental transport of ozone and its precursors. They analysed the impact of $10 \%$ anthropogenic emission changes from the regions Europe, USA, and Asia, respectively. They found 
roughly the same impact from emissions from USA and Europe to the ozone budget of the European upper troposphere, which is in agreement with our findings showing a more than $2 \%$ contribution from USA and Europe each. For Asia, Wild et al. found that one third of the upper troposphere ozone changes arise from European and USA emissions, agreeing with our findings showing a $1.5 \mathrm{ppb}$ contribution of European and USA road traffic contributions to ozone out of a total of $4 \mathrm{ppb}$.

\section{Summary and conclusions}

Our results indicate that in July 1990 road traffic emissions $\left(\mathrm{NO}_{\mathrm{x}}, \mathrm{CO}\right.$, and $\left.\mathrm{NMHCs}\right)$ contribute to the zonally averaged tropospheric ozone concentration by more than $12 \%$ in Northern Hemisphere midlatitudes and arctic latitudes. In January, road traffic contributes near the surface both in northern and southern extratropics more than $8 \%$. Relative contributions near the surface to northern hemispheric midlatitudes ozone amount to more than $12 \%$ in remote regions. The simulations with ECHAM4/CBM show that the exclusive consideration of $\mathrm{NO}_{\mathrm{x}}$ for assessing the impact of road traffic emissions neglects an important impact due to NMHC emissions. This holds in particular for the consequences of long range transport of emissions for atmospheric ozone in remote regions which is underestimated by about $30 \%$ when only considering $\mathrm{NO}_{\mathrm{x}}$ and $\mathrm{CO}$ emissions. For assessing the climate impact of road traffic emissions NMHCs have to be considered. Our regional studies have emphasised the regional and long-range contributions to ozone enhancement in the free troposphere, showing that global emission distributions have to be well known even for regional ozone studies in the free troposphere. Future increase in southern hemispheric regions, e.g. due to economic development in these regions will lead to comparative high ozone contributions to atmospheric ozone.

Acknowledgements. BMW AG funded part of the work of S. Matthes. Special thank goes to M. Ponater for ongoing support and constructive comments.

Edited by: F. J. Dentener

\section{References}

Atkinson, R.: Gas-phase tropospheric chemistry of organic compounds: a review, Atmos. Environ., 24A, 1-41, 1990.

Benkovitz, C., Scholtz, M., and Pacyna, J.: Global gridded inventories of anthropogenic emissions of sulfur and nitrogen, J. Geophys. Res., 101, 29 239-29253, 1996.

Crutzen, P., Lawrence, M., and Pöschl, U.: On the background photochemistry of tropospheric ozone, Tellus, 51A-B, 123-146, 1999.

Gery, M., Whitten, G., Killus, J., and Dodge, M.: A photochemical kinetics mechanism for urban and regional scale modelling, Geophys. Res. Lett., 94, 12 925-12 956, 1989.
Granier, C. and Brasseur, G.: The impact of road traffic on global tropospheric ozone, Geophys. Res. Lett., 30, 1086, doi:10.1029/2002GL015972, 2003.

Hao, W. and Liu, M.: Spatial and temporal distribution of tropical biomass burning, Global Biogeochem. Cycles, 8, 495-503, 1994.

Houweling, S., Dentener, F., and Lelieveld, J.: The impact of nonmethane hydrocarbon compounds on the tropospheric photochemistry, J. Geophys. Res., 103, $10673-10696,1998$.

IPCC: Special Report Emission Scenarios, Tech. rep., Intergovernmental Panel on Climate Change, Cambridge University Press, New York, NY, USA, 2000.

Lauer, A., Dameris, M., Richter, A., and Burrows, J.: Tropospheric $\mathrm{NO}_{2}$ columns: a comparison between model and retrieved data from GOME measurements, Atmos. Chem. Phys., 2, 67-78, 2002 , http://www.atmos-chem-phys.net/2/67/2002/.

Liu, S., McFarland, M., Kley, D., Mahlman, J., and Levy II, H.: On the origin of tropospheric ozone, J. Geophys. Res., 85, 15879 $15888,1980$.

Liu, S., Trainer, M., Fehsenfeld, F., Parrish, D., Williams, E., Fahey, D., Hübler, G., and Murphy, P.: Ozone production in the rural troposphere and the implication for regional and global ozone distribution, J. Geophys. Res., 92, 4191-4207, 1987.

Martin, R., Chance, K., Jacob, D., Kurosu, T., Spur, R., Bucsela, E., Gleason, J., Palmer, P., Bey, I., Fiore, A., Li, Q., Yantosca, R., and Koelemeijer, R.: An improved retrieval of tropospheric nitrogen dioxide from GOME, J. Geophys. Res., 107(D20), 4437, doi:10.1029/2001JD001027, 2002.

Matthes, S.: Globale Auswirkung des Straßenverkehrs auf die chemische Zusammensetzung der Atmosphäre, Ph.D. thesis, Ludwig-Maximilians Universität München, 2003.

Matthes, S. and Sausen, R.: Abschätzung der Emissionen in den EU-15 Staaten im Zeitraum 1980 bis 2015, Tech. rep., German Space Center (DLR), Oberpfaffenhofen, Germany, 2000.

OECD: Motor vehicle pollution, Tech. rep., OECD Organisation for economic co-operation and development, Paris, France, 1995.

Olivier, J., Bouwman, A., van der Maas, C., Berdowski, J., Veldt, C., Bloos, J., Visschedijk, A., Zandveld, P., and Haverlag, J.: Description of EDGAR 2.0: A set of global emission inventories of greenhouse gases and ozone depleting substances for all anthropogenic and most natural sources on a per country basis on a $1^{\circ} \times 1^{\circ}$ grid, Tech. rep., RIVM, Bilthoven, Netherlands, 1996.

Richter, A. and Burrows, J.: Retrieval of Tropospheric $\mathrm{NO}_{2}$ from GOME Measurements, Adv. Space Res., 29, 1673-1683, 2002.

Roeckner, E., Arpe, K., Bengtsson, L., Christoph, M., Claussen, M., Dümenil, L., Esch, M., Giorgetta, M., Schlese, U., and Schulzweida, U.: The Atmospheric General Circulation Model ECHAM-4: Model Description and Simulation of Presentday Climate, Tech. rep., Max-Planck-Institute for Meteorology, Hamburg, Germany, 1996.

Roelofs, G.-J. and Lelieveld, J.: A three dimensional chemistrygeneral circulation model: Influence of higher hydrocarbon chemistry, J. Geophys. Res., 105, 22 697-22 712, 2000.

Wild, O. and Akimoto, H.: Intercontinental transport of ozone and its precursors in a three-dimensional global CTM, J. Geophys. Res., 106, 27 729-27 744, 2001. 